\title{
Evaluation of carbon sequestration in tropical grassland, ecological processes and farm practices in Amazonian cattle systems
}

\author{
V. Blanfort ${ }^{1 \dagger}$, S. Fontaine ${ }^{2}$, C. Picon Cochard ${ }^{2}$, K. Klumpp ${ }^{2}$, J. Huguenin ${ }^{3}$ and J. F. Soussana ${ }^{2}$ \\ ${ }^{1}$ CIRAD UR 18, Livestock Systems BP 701-97387 Kourou Cedex - French Guyana; ${ }^{2}$ INRA UR0874, UREP Grassland Ecosystem Research, 234, Av. du Brézet, \\ Clermont-Ferrand, F-63100, France; ${ }^{3}$ CIRAD UR 18, Livestock Systems, Campus International de Baillarguet, Cedex 5, Montpellier F-34398, France
}

\section{Introduction}

The humid tropics have seen a considerable expansion in ruminant farming since the 1970 s (at present $25 \%$ of the world's ruminant stock). This situation is often criticized for its negative environmental impacts: deforestation, loss of biodiversity, greenhouse gas (GHG) production (carbon dioxide, methane, nitrous oxide). The increase of direct emissions from the agriculture sector (17\%) mostly occur in emerging countries like Brazil (IPCC, 2007). Although ruminant production systems are viewed as a major source of GHG emissions (18\% of global emissions according to FAO soil carbon (C) sequestration (SOC) the world's permanent pastures could potentially offset up to $4 \%$ of the global GHG emissions (Soussana et al., 2009; Steinfeld et al., 2010). This research, started in 2010, aims at identifying the carbon dynamics in pastures and define the management practices likely to compensate a part of the $\mathrm{C}$ losses resulting from their establishment (which was detrimental to the forest, Figure 1).

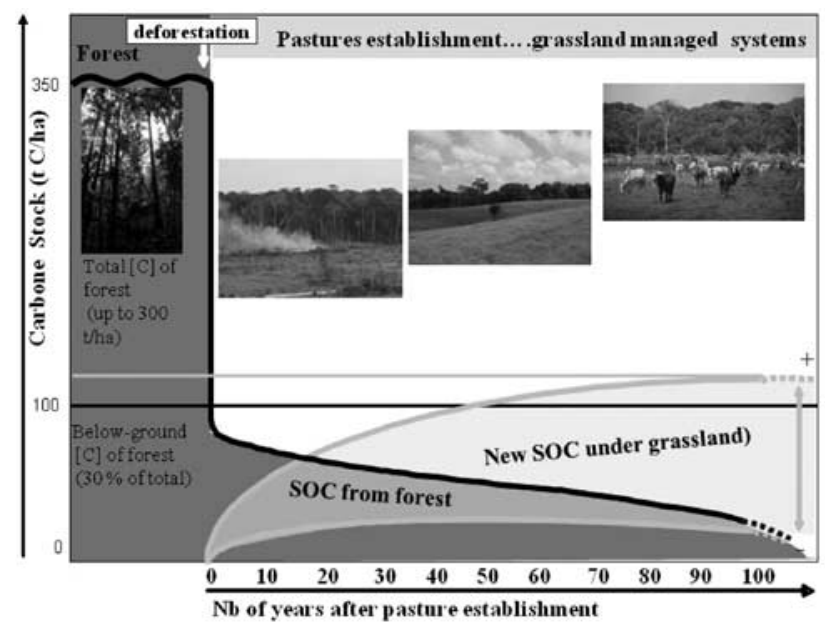

Fig. 1 Dynamics of SOC after deforestation and under grassland in Amazonia (hypothesis + or - depending on pasture management practices)

\section{Context and Hypothesis}

Livestock production produces $9 \%$ of global anthropogenic $\mathrm{CO}_{2}$ emissions, the largest share (i.e. $7 \%$ ) of this derives from land-use changes especially deforestation ( $25 \%$ of $\mathrm{CO}_{2}$ global emissions) - caused mainly by expansion of pastures and forage crops. In Amazonia, more than $50 \%$ of these pastures are abandoned and replaced by other grasslands established on newly deforested areas. Therefore it is important to know the fate of carbon in the soil after the forest has been transformed into grassland and to understand how these pastures can continue storing carbon in the soil (Figure 1) as well as keeping their fertility level.

\section{Methods and Results}

Carbon sequestration can be determined directly by measuring changes in C stocks (most of the Amazonian studies) but SOC stocks displays a high spatial variability which limits the accuracy of direct determinations of $C$ stock changes. An alternative is to measure the net balance of $C$ fluxes exchanged at the system boundaries (eddy flux covariance). There has not yet been any direct comparison at the same site between $C$ flux and $\mathrm{C}$ stock change measurements. The originality of this research consists in associating the two approaches and to compare $\mathrm{C}$ balance

\footnotetext{
${ }^{\dagger}$ E-mail: blanfort@cirad.fr
} 


\title{
Advances in Animal Biosciences
}

in deforested grassland to the original forest where similar measurements are in progress. While the Amazonian forest has considerable potential for trapping carbon-up to 300 t per hectare in French Guiana-the estimated quantity of carbon stored in the soil of grassland is very high. Carbon accumulation in grassland ecosystems (SOC) occurs mostly below ground due to active rhizodeposition, and the residence time in organic matter depends on management practices (Fontaine et al., 2007). In Amazonia, the reconstitution of $C$ in the soil after deforestation could reach more than 100 t/ha after decades according to studies based on C stock changes under pasture (Figure 1). The sink activity of temperate grassland can reach $1 \mathrm{t}$ of carbon per hectare per year (Soussana et al., 2009) and need to be validated in tropical conditions.

\section{Conclusions}

Current references on GHG emissions and mitigation by soil carbon (C) sequestration need to be completed to identify indicators and management practices able to strengthen the stability of deforested areas in humid tropics while attenuating their negative environmental impacts by more effectively providing certain ecosystemic services. These results could be adapted to tropical conditions at farm level to estimate the farm GHG balance.

\section{Acknowledgements}

These researches are co-funded by Europe FEDER (Fonds européen de développement regional).

\section{References}

Fontaine S, Barot S, Barré P, Bdioui N, Mary M and Rumpel C 2007. Stability of organic carbon in deep soil layers controlled by fresh carbon supply. Nature 450, $277-280$. Soussana JF, Tallec T and Blanfort V 2009. Mitigating the greenhouse gas balance of ruminant production systems through carbon sequestration in grasslands. Animal (2010) 4 (3), 334-350. doi:10.1017/S1751731109990784.

Steinfeld H, Mooney HA, Schneider F and Neville LE (eds) 2010. Livestock in a Changing Landscape, Volume 1, Drivers, Consequences, and Responses. Island Press, Washington, DC.

\section{Milk production in small farms in Haiti: the "Let agogo" (milk in abundance) experience}

\author{
Museau Hérault ${ }^{\dagger}$, Rosanie Moise and Michel Chancy \\ Veterimed, Organisation Non Gouvernementale, 178 Ruelle Alerte, Port-au-Prince, Haiti
}

\section{Introduction}

Every year Haiti imports more than 40 million Euros worth of milk products. Milk is no less than the second category of food imports into the country. To deal with this situation, Haitian producers organize and develop sustainable alternate strategies with support from young professionals. "Lèt Agogo" has been developed by the NGO Veterimed (Veterimed, 2007, 2010).

Veterimed is a Haitian NGO that works to support development in Haiti. It was created in 1991 by a group of Haitian professionals who wanted to contribute to national development in the rural sector. Some 700000 families of small farmers ensure around $90 \%$ of the livestock production in Haiti (Veterimed, 2010). For the most part, these producers did not receive any technical support. Veterimed's mission is to help small Haitian farmers increase their income and improve their quality of life through training, research and technical support in the areas of animal health and production. The focus consists in step-by-step improvements to traditional production issues in order to increase profitability and sustainability, and thus contribute to significant improvements in farmers' incomes. Their objective is to work with farmers to ensure sustainable alternatives in livestock development. Veterimed supports small, family farming because it creates and maintains jobs in the countryside, is more environmentally-sound and socially more equitable. Local vegetal and animal resources are used.

For about 10 years, "Lèt agogo" (milk in abundance) project has been contributing to decrease milk importation, developing local milk production based on network of small farms. The "Lèt agogo" project works to increase milk production in order to increase farmer's family income, as well as commercialization opportunities. Today "Lèt agogo" is also the brand name for the milk products (yogurt and sterilized milk) produced by a network of micro transformation units and distributed across the country with support from many youth and rural organizations.

\footnotetext{
${ }^{\dagger}$ E-mail: mushe78@gmail.com
} 